\title{
DISASTER VICTIM IDENTIFICATION (DVI) TRAINING FOR MEDICAL STUDENT
}

\author{
Taufik Suryadi ${ }^{1 *}$, Kulsum Kulsum² \\ ${ }^{1}$ Department of Forensic Medicine and Medico-legal, Faculty of Medicine, Universitas Syiah Kuala, Darussalam-Banda Aceh - \\ INDONESIA \\ ${ }^{2}$ Department of Anaesthesiology and Intensive Care, Faculty of Medicine, Universitas Syiah Kuala, Darussalam-Banda Aceh - \\ INDONESIA
}

Submitted: 05 February 2020; Final Revision from Author: 08 July 2020; Accepted: 13 July 2020

\section{ABSTRACT}

Background: Disaster victim identification (DVI) is a process of identifying the victim who died due to the disaster. Deaths due to disasters can be classified as victims of open disasters and victims of closed disasters. In the open disasters the process of identification is more difficult. Based on regulation of law in Indonesia, the identification is intended to fulfil human rights to identity, dignity and social status, autonomy rights such as inheritance, marital status, religion, insurance or other legal and social issues.

Aims: The purpose of this curriculum study is to provide an overview of the DVI training process for medical students.

Curriculum Discussion: Given the importance of the identification process it is necessary to be included in the medical education curriculum. The DVI training to identify victims of mass disasters uses the DVI Interpol standard. Faculty of Medicine Universitas Syiah Kuala has conducted training and simulations of DVI for medical student since 2009 until 2019. A total of 1995 students in this period have participated in the training. The DVI training for medical students is very needed as an addition to the competence of doctors in the field of disaster management.

Conclusion: By joining this training, medical students have sufficient medical skills to assist in the process of DVI.

Keywords: DVI training, Disaster management, Medical competence

\section{ABSTRAK}

Latar belakang: Disaster victim identification (DVI) adalah proses mengidentifikasi korban yang meninggal akibat bencana. Kematian akibat bencana dapat diklasifikasikan sebagai korban bencana terbuka dan korban bencana tertutup. Dalam bencana terbuka proses identifikasi lebih sulit. Berdasarkan peraturan hukum di Indonesia, identifikasi dimaksudkan untuk memenuhi hak asasi manusia atas identitas, martabat dan status sosial, hak otonomi seperti warisan, status perkawinan, agama, asuransi atau masalah hukum dan sosial lainnya.

Tujuan: Tujuan dari studi kurikulum ini adalah untuk memberikan gambaran umum tentang proses pelatihan DVI untuk mahasiswa kedokteran.

Diskusi kurikulum: Mengingat pentingnya proses identifikasi, maka perlu dimasukkan dalam kurikulum pendidikan kedokteran. Pelatihan DVI untuk mengidentifikasi korban bencana massal menggunakan standar DVI Interpol. Fakultas Kedokteran Universitas Syiah Kuala telah melakukan pelatihan dan simulasi DVI untuk mahasiswa kedokteran sejak

*corresponding author, contact: taufiksuryadi@unsyiah.ac.id 
2009 hingga 2019. Sebanyak 1995 mahasiswa pada periode ini telah berpartisipasi dalam pelatihan ini. Pelatihan DVI untuk mahasiswa kedokteran sangat dibutuhkan sebagai tambahan kompetensi dokter di bidang manajemen bencana.

Kesimpulan: Dengan mengikuti pelatihan ini, mahasiswa kedokteran memiliki keterampilan medis yang cukup untuk membantu dalam proses DVI.

Kata kunci: pelatihan DVI, manajemen bencana, kompetensi medis

\section{PRACTICE POINTS}

- DVI training and simulation add to the competence of medical students in the field of disaster management.

- The ability to disaster victim identification is very much needed in disaster-prone areas such as Aceh province.

\section{INTRODUCTION}

Indonesia is an archipelago's country which geographically, geologically, hydrologically, and demographically are higher risk of disaster because it is located between two oceans namely the Pacific ocean and the Indonesian oceans, two continents namely Asia and Australia and also surrounded by plates starting from the Euro-Asia, IndoAustralia and Pacific plates. ${ }^{1}$ Demographically, Indonesia consists of various races, ethnicities, religions, social state that can lead to conflict both social and humanity. ${ }^{2}$ Disasters in Indonesia which occur throughout the world caused by natural factors such as earthquake and tsunami, non- natural factors and human factors that can cause destruct human life, environmental damage, property losses, and psychological impacts. ${ }^{3}$ Geographical, geological, and hydrological conditions are the biggest risk factor of disasters in Indonesia. Indonesia is an archipelago with a group of islands stretching from Sabang in Aceh province to Merauke in Papua province, with a total about five million square kilo meters, is a region that is very risky. In addition, the tropical climate also increases the risk of heavy rainfall, flooding and landslides, but also some regions experience drought. $^{4}$

Banda Aceh is the capital city of Aceh Province, an area in Indonesia which is also very risky for disasters because it lies at the confluence of two seas with a very long coastline, the Malacca Strait and the Indonesian ocean, the position is not too far from mount Seulawah in the south, and many large rivers surrounding it. The biggest disaster that ever happened in Aceh, Indonesia and some parts of south-east Asia was the earthquake and tsunami of 2004 which caused a lot of injuries, disappearances or deaths. This incident made the world aware of the importance of disaster management. Responding to this condition, in Thailand, the Thai Tsunami Victim Identification Centre (TTVIC) ${ }^{5}$ and in Banda AcehAceh Province, Indonesia, the Tsunami and Disaster Mitigation Research Centre (TDMRC) study centre was established. The massive earthquake in Sumatra which reached 9.0 Richter scale with the epicentre on the west coast of Aceh-Indonesia caused the Tsunami on December 26th, 2004 caused a serious impact on human lives, property, communication and natural resources, not only in Indonesia but also in several parts of Asia and Africa. It is estimated that more than 232 thousand people died and disappeared. ${ }^{6}$

Based on the conditions and disaster situations that have occurred in Indonesia generally and in Aceh particularly, as an educational institution, the Faculty of Medicine Universitas Syiah Kuala, which has been very concerned with disaster management since 2006, has carried out disaster management education activities ranging according to disaster management cycle from World Health Organization (WHO) recommendation, namely disaster risk management such as prevention, mitigation, preparedness, and disaster crisis management such as live victims management and dead victims management. The live victim management is rapid health assessment 
including basic life support, disaster triage, and hospital field. The dead victim management including disaster victim identification to reconstruction, rehabilitation and recovery post-disaster. ${ }^{7,8}$

According to the Law of Republic of Indonesia number 36 in 2009 concerning about health, has given mandate to the government and the community to make efforts to identify disaster victims. ${ }^{9}$ The purpose of the disaster victim identification who have died legally is intended to fulfil human rights - victims of disasters - so that their identities can be identified. ${ }^{8}$ If the identity of a disaster victim is identified, it can be returned to the family and properly buried according to his/ her religion and beliefs during his/her lifetime. The determination of identity of the victim is a must with a high accuracy considering the various interests of both legal, medical and social as in matters of inheritance rights, marital status, and insurance or legal problems and other social institutions. ${ }^{8,10,11}$

Given the importance of the identification process it is necessary to be included in the medical education curriculum. In the implementation of medical education in Medical Faculty of Universitas Syiah Kuala used teaching and training in medical treatment of living and dead victims. Generally, teaching and training for handling the living victims have been discussed in related modules such as emergency, traumatology, and modules for each disease handled by the medical team and other support teams. However, it is different for victims who have died, it needs dead victims management and special handling by the identification team which consist of forensic medicine team and other identification teams. ${ }^{8}$

A case study was reported about DVI training activities at the medical school. The purpose of this training is to increase the competence of medical students in the process of disaster management, especially identification of disaster victims considering that the province of Aceh is a disasterprone area in Indonesia. The purpose of this case study is to provide an overview of the DVI training process for medical students.

The current process of identification of disaster's victims in Indonesia uses guideline from the Disaster Victim Identification (DVI) protocol from international police (Interpol). ${ }^{8.12}$ Disaster Victim Identification (DVI) from Interpol DVI Guideline is an international standard and scientifically and legally has been justified by Indonesian law. ${ }^{13}$

This is a retrospective case report without the use of any samples from human subject, so ethical approval can be waived.

\section{CURRICULUM DESCRIPTION}

Disaster Management module in Medical Faculty of Universitas Syiah Kuala then held DVI training that has lasted for 11 years began in 2009 until 2019 for the students of class 2006 to $2016 . .^{7}$ Since 2009 to 2019 the number of medical students who have followed the DVI training amounted to 1995 participants. ${ }^{14}$ The trainee in DVI training is shown in table 1.

Table 1. Number of participants in DVI training ${ }^{14}$

\begin{tabular}{cccccc} 
No. & Year & Participant & $\begin{array}{c}\text { Number of } \\
\text { Students }\end{array}$ & $\begin{array}{c}\text { Number of Grid } \\
\text { Location }\end{array}$ \\
\hline 1 & 2009 & Student class of 2006 & 176 & 15 & Medical faculty \\
2 & 2010 & Student class of 2007 & 176 & 15 & Medical faculty \\
3 & 2011 & Student class of 2008 & 199 & 17 & Medical faculty \\
4 & 2012 & Student class of 2009 & 183 & 16 & Medical faculty \\
5 & 2013 & Student class of 2010 & 159 & 14 & Medical faculty \\
6 & 2014 & Student class of 2011 & 249 & 21 & Medical faculty \\
7 & 2015 & Student class of 2012 & 251 & 21 & Medical faculty \\
8 & 2016 & Student class of 2013 & 200 & 17 & Medical faculty \\
9 & 2017 & Student class of 2014 & 128 & 10 & Medical faculty \\
10 & 2018 & Student class of 2015 & 126 & 10 & Medical faculty \\
11 & 2019 & Student class of 2016 & 148 & 14 & Medical faculty \\
\hline \multicolumn{7}{r}{} \\
\hline
\end{tabular}


Before beginning to DVI training, the student has given a simulation scenario, for example in DVI training in 2019, the scenario is: At a shopping centre has occurred a bomb blast that killed at least 15 people consisting of 8 men and 7 women. The identification is difficult to be held because the type of open disaster that possible anyone to become a victim. Task: perform DVI operation in the above case, checking what's needed to be done.

In DVI training activities, all students are divided by classes (grid). One class consists of $11-13$ people, each class performs a DVI operation called a grid, all students has their own assignment, for example, as DVI commander, sketch drawer, photographer, body part searcher, property searcher, evacuator, post mortem data collector, and ante mortem data collector.

In the post mortem data collection phase, junior students are willing to act as volunteers who play the role as the victims of disasters. The students are made use of moulage in such a way that they are similar to actual disaster victims. The students who are undergoing training carry out the DVI procedure in the post mortem data collection phase by examining the volunteer victims. In the ante mortem data collection phase, volunteers are also used as victims 'families, who are willing to be victims' families are senior students.

\section{DISCUSSION}

The Medical Faculty of Universitas Syiah Kuala, which has a disaster management module, conducts DVI training annually as one of its leading competencies. $^{7}$ In DVI training in Medical Faculty of Universitas Syiah Kuala also uses the DVI Interpol protocol. Students are given training on how to carry out the process of identifying disaster victims through disaster simulations. In DVI training, the students were divided into five groups, namely the role of team scene investigation including searching, labelling, and evacuation, post mortem team, ante mortem team and reconciliation team. The task of the student in the training is identifying mass casualties in phase 1, 2, 3, 4 and 5 according to DVI protocol. One of the student as DVI commander, and the others in group 1 are responsible to drawing sketches and photographers, group 2 are responsible to searching the evidence and the givers label, group 3 are responsible to personnel evacuation, group 4 are responsible as the examiner of post mortem data, group 5 are responsible as the examiner of ante mortem data and reconciliation officers. ${ }^{7}$

Theoretically, in DVI operation, an accurate identification are doing by matching the data ante mortem and the data post mortem. In general there are two main methods of identification, namely: a) simple methods, namely visual, property ownership (jewellery and clothing) and documentation (identity card, passport, driving license) and b) scientific methods, namely fingerprints, serology, odontology, anthropology, molecular biology, radiology imaging and techniques superimposition. ${ }^{15}$ Specifically in mass disaster, identification of the victims based on the standard of Interpol for the identification process. In operation DVI predetermined identification method used, namely: a) primary identification, such as fingerprints, dentition, analysis deoxyribonucleic acid (DNA) and b) secondary identification, namely medical, property, photography/visual. $8,12,13$

Determining whether a victim has been identified is if there is a match of one data from primary identification or at least two data from secondary identification. The principle in working for the DVI operation is team work in accordance with expertise/competence and experience. Process of DVI includes 5 phases, which each phase is linked with one another, consisting of: phase 1 Scene investigation, phase 2 - Post-mortem, phase 3 - Ante mortem, phase 4 - Reconciliation and phase 5-Debriefing. ${ }^{8,12,13}$ The process of identification is composed of five distinct phases, starting from the discovery of the body of the victim, ante mortem data collection, post mortem data collection and finally comparing two data to reconciliation and identify. ${ }^{16}$

The role of students of faculty of medicine Universitas Syiah Kuala at every phase of the identification of disaster victims can be described as follows: 
a. The first phase, the initial team that came to the scene performed to search a victim died under the command of DVI commander. DVI commander asked the sketching team and the photographer to make a picture of the location of the incident and take photos of three positions namely close up, close and the whole body of the victim, after which the team found evidence in the form of a dead victim (body part) and the victim's property. The dead victims (played by junior students and mannequins) are labelled as orange markers, and the property (model or duplicated objects) is labelled green. This label contains information on the examining team (group/ class), location of the discovery (grid), and body / body number or property number. This label will be very helpful in the next identification process. Then enter the evacuation team that carries the body and property to the post mortem examination room. ${ }^{12,13,17,18}$

b. The second phase in the DVI process is the post mortem phase. This phase can take place simultaneously with the first and third phases. In this phase, the students conduct an examination to look for as much post mortem data. In this phase, a team of forensic pathologists (played by students) to examine the whole body, ${ }^{17,19}$ if the body remains skeleton, the role of forensic anthropologists (played by students) is more dominant. ${ }^{19.20}$ Other tests such as simulation examination finger print, examination of odontology, ${ }^{21}$ and belongings attached to the corpse and also carried out simulation of tissue sampling for DNA examination. This data was entered into the pink form based on the Interpol standard. ${ }^{12,13,17,18,19,20}$

c. The third phase is the ante mortem data collection phase. In this phase students receive reports of people / families (played by senior students) who have lost family members who are suspected to be victims. Students request as much data input from the victim's family. The requested data starts from the last clothes worn, special characteristics (birthmarks, tattoos, moles, exsurgery, etc.), medical record data from the family doctor and dentist of the victim, fingerprint data from the authorities (village or police), as well as DNA prints if the family owns it. If there is no DNA data from victims, a blood sample is taken from the victim's family. Simulation collecting the ante mortem data is loaded into the yellow form according to DVI guideline Interpol standards. ${ }^{12,13,16,18,19}$

d. The fourth phase is reconciliation. Students together with training instructors conduct reconciliation. A person is identified if there is a match between the ante mortem and post mortem data with the criteria of at least 1 type of primary identification or 2 kinds of secondary identification with or without primary identification. ${ }^{12,13}$ Constraints that often occur at the time of identification are inconsistent ante mortem data and lack of ante mortem data such as fingerprints, teeth or DNA profile. Less than $10 \%$ of Indonesian people are known for fingerprints, dental examinations are also rarely done let alone make a DNA profile making it difficult to identify. ${ }^{21,22,23}$

e. The Fifth phase. After completing the entire identification process, with satisfactory results or not, the training process for identifying the victims of the disaster will proceed to the debriefing phase.$^{13}$ In the training, in the debriefing phase, all people involved such as instructors, students, senior students, junior students and supporting staff in the identification training process gathered to conduct an evaluation of all matters relating to the implementation of the DVI training process both facilities, infrastructure, performance from students, instructor, procedures, and identification results. 
Table 2. The role of students in the DVI training ${ }^{17}$

\begin{tabular}{|c|c|c|}
\hline Phases & Student role & Activity \\
\hline \multirow[t]{4}{*}{ Crime scene } & DVI commander & Leading DVI operations, coordinating classroom activities \\
\hline & $\begin{array}{l}\text { Drawing } \\
\text { sketches and } \\
\text { photographers }\end{array}$ & $\begin{array}{l}\text { 1. Determine the extent of the crime scene } \\
\text { 2. Map the coverage of disaster and make coordinates of disaster area } \\
\text { 3. Sketching a crime scene } \\
\text { 4. Estimating the number of victims } \\
\text { 5. Taking pictures of crime scenes }\end{array}$ \\
\hline & $\begin{array}{l}\text { Search for } \\
\text { evidence and } \\
\text { labellers }\end{array}$ & $\begin{array}{l}\text { 1. Search for victims } \\
\text { 2. Labelling victims and property, orange labelling for body } \\
\text { parts, green labelling for property }\end{array}$ \\
\hline & Evacuation Officer & $\begin{array}{l}\text { 1. Move the victim from the crime scene to the post mortem unit } \\
\text { 2. Submit victims and property to the post mortem team }\end{array}$ \\
\hline Post mortem & $\begin{array}{l}\text { Post mortem data } \\
\text { checker }\end{array}$ & $\begin{array}{l}\text { Make documentation of the victim by capturing a photo of the condition } \\
\text { of the victim's body } \\
\text { Conducting an external physical examination } \\
\text { Plan an autopsy check if necessary } \\
\text { Planning a fingerprint check } \\
\text { Plotting roentgen examination } \\
\text { Planning a forensic odontology examination } \\
\text { Plotting DNA examination } \\
\text { Perform a forensic anthropology examination }\end{array}$ \\
\hline Ante mortem & $\begin{array}{l}\text { Ante mortem data } \\
\text { checker }\end{array}$ & $\begin{array}{l}\text { Collecting data about the victim before death was obtained from the } \\
\text { body of the corpse and the person closest to the body. } \\
\text { Collecting data obtained can be in the form of photos of victims during } \\
\text { life, interpretation of specific features of the body (tattoos, piercings, } \\
\text { scars, etc.), } \\
\text { Collecting records of victims' dental examinations, } \\
\text { Collecting fingerprint data of the victim during life } \\
\text { Collect DNA samples of parents and relatives of victims } \\
\text { Gather other relevant information that can be used for identification } \\
\text { purposes, for example information about the last clothes worn by the } \\
\text { victim. }\end{array}$ \\
\hline Reconciliation & $\begin{array}{l}\text { Reconciliation } \\
\text { officer }\end{array}$ & Comparing post mortem data with ante mortem data. \\
\hline Debriefing & All teams & $\begin{array}{l}\text { Determine the results of identification of disaster victims } \\
\text { Hand over the victims to the family } \\
\text { Evaluating activities }\end{array}$ \\
\hline
\end{tabular}

The activities of DVI training in 2019 can be seen in video that produced by medical student in https:// youtu.be/8 dBo50uB2U. 24 The role of students in the DVI training can be seen in table $2 .{ }^{17}$ Evaluation of the implementation of DVI training in the last 10 years has shown progress. The evaluation results of this programme showed a significant number of students' knowledge and skills. In the 2019 DVI training, the enthusiasm of students following the training was seen, the instructor had also conducted a test of responsiveness to student knowledge and the results were quite satisfying. The role played by students looks natural and student behaviour is also very good and shows an attitude of professionalism.

The medical education curriculum at the Faculty of Medicine at the Universitas Syiah Kuala, which includes the disaster management module as a flagship module, is considered to be very relevant to the situation and conditions of the disasterprone region of Aceh. The experience during the 2004 earthquake and tsunami in Aceh with so 
many unidentified victims was the main reason for the institution to create a disaster management curriculum and include DVI training as one of the field practicums. From year to year it is felt very important for this institution to continue to provide additional competence for students in the field of disaster management.

The strength of this case study is that the implementation of DVI training has lasted more than one decade and has been described in detail how the DVI training has been carried out. The limitation of this case study is that the DVI training was reported only in 2019 for student class of 2016, so the case study results might not reflect all students who had undergone previous DVI training, although basically all DVI training in previous years was relatively the same as using the DVI Interpol standard. It may also not be relevant to the experience of medical students at other institutions. But in general, the DVI training is very useful for the development of disaster management systems in the future.

\section{CONCLUSION}

DVI training in Medical Faculty of Universitas Syiah Kuala for students plays a role in improving students' medical skills in terms of determining individual identity. In the process of DVI training, students are able to do a crime scene simulation, collect ante-mortem and postmortem data and be able to make comparisons between the ante-mortem and post-mortem data so it can increase the student competency generally in the field of disaster management.

\section{RECOMMENDATION}

With this case study, there is an illustration of how the DVI training has been carried out since the last decade in the Medical Faculty of the Universitas Syiah Kuala. Further research needs to be done on how students' cognitive retention and skills towards DVI and it is hoped that other institutions in Indonesia can also implement DVI training and be included in the medical education curriculum.

\section{COMPETING INTEREST}

The authors declare that there are no competing interests related to the study

\section{AUTHORS' CONTRIBUTION}

Taufik Suryadi - as a forensic medicine specialist and ethics-medicolegal consultant, who is responsible for the DVI training and to make basic concept in the manuscript preparation.

Kulsum Kulsum - as an anaesthesiologist and neuroanaesthesia consultant, who is responsible for final editing in the manuscript preparation. TS and KK both read and improved the manuscript in accordance with the suggestions of the reviewers. This manuscript has been approved by the authors.

\section{REFERENCES}

1. Kementerian Kesehatan Republik Indonesia. Pedoman Perencanaan Penyiagaan Bencana bagi Rumah Sakit. Jakarta: Kemenkes RI; 2009.

2. Toha M. Berkawan dengan ancaman: Strategi dan Adaptasi Mengurangi Risiko Bencana. J Walhi; 2007.

3. Badan Nasional Penanggulangan Bencana (BNPB). Kerangka Kerja Sendai untuk Pengurangan Risiko Bencana 2015-2030. Jakarta: BNPB; 2015.

4. Prawestingingtyas E, Algozi AM. Identifikasi forensik berdasarkan pemeriksaan primer dan sekunder sebagai penentu identitas korban pada dua kasus bencana massal. Jurnal Kedokteran Brawijaya. 2009;25(2):87-94.

5. Lessig R, Rothschild M. International standard in cases of mass Disaster Victim Identification (DVI). Forens Sci Med Pathol. 2011.

6. Beauthier JP, Valck ED, Levefre P, De Winne J. Mass Disaster Victim Identification: The Tsunami Experience. Forens Sci J. 2009;2:54-62.

7. Rahman S, Oktari RS, Suryadi T, Jasa ZK, Andayani H, Akbar TIS. Buku tutor Blok Disaster Manajemen. Banda Aceh: Fakultas Kedokteran Universitas Syiah Kuala; 2017. 
8. Poernomo S, Salehangi P, Yosephine L, Agus M. Pedoman Penatalaksanaan Identifikasi Korban Mati pada Bencana Massal. Jakarta: Departemen Kesehatan Republik Indonesia dan Kepolisian Negara Republik Indonesia; 2004, pp 1-234.

9. Republik Indonesia. Undang-Undang Nomor 36 Tahun 2009 Tentang Kesehatan.

10. Amir A. Rangkaian Ilmu kedokteran forensik. Edisi kedua. Medan: Bagian Ilmu Kedokteran Forensik dan Medikolegal Fakultas Kedoktean USU; 2005.

11. Idries AM, Tjiptomartono AL. Penerapan Ilmu Kedokteran Forenik dalam Proses Penyidikan. Jakarta: Sagung Seto; 2008.

12. International Criminal Police Organization. Disaster Victim Identification Guide, GB Version: 2011.

13. Saparwoko E. DVI in Indonesia: an overview, in DVI Workshop, Bandung 25-26 November 2006.

14. Universitas Syiah Kuala. Data Mahasiswa-Data akademik. Available at: https://krsonline. unsyiah.ac.id.2019.

15. Bagian Kedokteran Forensik Fakultas Kedokteran Universitas Indonesia. Identifikasi Forensik, dalam Ilmu Kedokteran Forensik. Jakarta: FK UI; 1997, pp.197-202.

16. Schuliar Y, Knudsen PJT, Role of forensic pathologists in mass disaster. Forens Sci Med Pathol. 2012;8:164-73.
17. Suryadi T. Modul Praktikum Identifikasi Korban Bencana. Blok Disaster Management Fakultas Kedokteran Universitas Syiah Kuala. Banda Aceh: FK Unsyiah; 2017.

18. Singh S. Penatalaksanaan Identifikasi Korban. Maj.Ked.Nusantara. Fakultas Kedokteran Universitas Sumatera Utara, 2008;41:255-6.

19. Khoo LS, Aziz S, Mahmood MS. Beyond DVI: Future identification, research and archiving. Forens Sci Crimino. 2016;1(1):1-5.

20. Blau S, Briggs CA. The role of forensic anthropology in Disaster Victim Identification. Forens Sci Int. 2011;205:29-35.

21. Kolude B, Adeyemi BF, Taiwo JO, Sigbeku OF, Eze UO. The role of forensic dentist following mass disaster. Annual of Ibadan Postgraduate Medicine. 2010;8(2):111-7.

22. Budowle B, Bieber FR, Eisenberg AJ. Forensic aspect of mass disasters: Strategic considerations for DNA-based human identification. Legal Medicine. 2005; 7:230-43.

23. Monica GL, Siwu JF, Mallo JF. Identifikasi personal dan identifikasi korban massal di BLU RSUP Prof Dr R.D.Kandou Manado periode Januari 2010-Desember 2012. J Biomedik. 2013;5(1):119-26.

24. Mulya PN. Praktikum DVI (Disaster Victim Identification). Fakultas Kedokteran Universitas Syiah Kuala; 2019. Video. Available at: https:// youtu.be $/ 8$ dBo50uB2U 